\title{
Reductase Domain of Drosophila melanogaster Nitric-Oxide Synthase: Redox Transformations, Regulation, and Similarity to Mammalian Homologues ${ }^{\dagger}$
}

\author{
Sougata Sinha Ray,,$\perp$ Rajib Sengupta, ${ }^{\ddagger}$ Mauro Tiso," Mohammad Mahfuzul Haque," Rupam Sahoo,

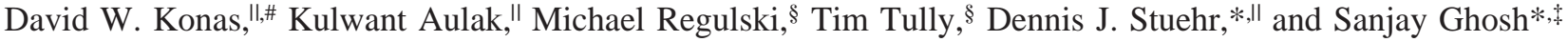 \\ Department of Biochemistry, University College of Sciences, Calcutta University, West Bengal 700 019, India, Cold Spring \\ Harbor Laboratory, Cold Spring Harbor, New York, and Department of Pathobiology, The Lerner Research Institute, \\ The Cleveland Clinic, Cleveland, Ohio 44195
}

Received April 27, 2007; Revised Manuscript Received August 3, 2007

\begin{abstract}
The nitric oxide synthase of Drosophila melanogaster (dNOS) participates in essential developmental and behavioral aspects of the fruit fly, but little is known about dNOS catalysis and regulation. To address this, we expressed a construct comprising the dNOS reductase domain and its adjacent calmodulin $(\mathrm{CaM})$ binding site $(\mathrm{dNOSr})$ and characterized the protein regarding its catalytic, kinetic, and regulatory properties. The $\mathrm{Ca}^{2+}$ concentration required for $\mathrm{CaM}$ binding to dNOSr was between that of the mammalian endothelial and neuronal NOS enzymes. CaM binding caused the cytochrome $c$ reductase activity of dNOSr to increase 4 times and achieve an activity comparable to that of mammalian neuronal NOS. This change was associated with decreased shielding of the FMN cofactor from solvent and an increase in the rate of NADPH-dependent flavin reduction. Flavin reduction in dNOSr was relatively slow following the initial 2-electron reduction, suggesting a slow inter-flavin electron transfer, and no charge-transfer complex was observed between bound $\mathrm{NADP}^{+}$and reduced FAD during the process. We conclude that dNOSr catalysis and regulation is most similar to the mammalian neuronal NOS reductase domain, although differences exist in their flavin reduction behaviors. The apparent conservation between the fruit fly and mammalian enzymes is consistent with dNOS operating in various signal cascades that involve NO.
\end{abstract}

Nitric oxide synthase enzymes (NOS, EC 1.14.13.39) ${ }^{1}$ convert L-arginine to nitric oxide (NO) and citrulline by catalyzing a stepwise, NADPH- and $\mathrm{O}_{2}$-dependent reaction $(1-3)$. NOS enzymes are found throughout the animal, insect, and bacterial kingdoms and participate in a wide variety of biological signaling and self-defense pathways (314). They contain independently folding heme (oxygenase) and flavoprotein (reductase) domains that are connected to one another by a central calmodulin $(\mathrm{CaM})$ binding sequence. The NOS oxygenase domain catalyzes NO synthesis and is supported by NADPH-derived electrons provided by the

$\dagger$ This work was supported by Department of Science and Technology (DST), Govt. of India and National Institutes of Health Grants GM51491 and HL76491 (to D.J.S.).

* To whom correspondence should be addressed. Department of Pathobiology, NC-22, Lerner Research Institute, The Cleveland Clinic, 9500 Euclid Ave., Cleveland, OH 44195. Phone: (216)-445-6950. Fax: (216)-444-9329. E-mail: stuehrd@ccf.org (D.J.S). Department of Biochemistry, University College of Sciences, Calcutta University, 35 Ballygunge Circular Road, Kolkata, West Bengal 700 019, India. Phone: +91-33-2461-5445. Fax: +91-33-2461-4849. E-mail: sgbioc@ caluniv.ac.in; ghoshs71@ @otmail.com (S.G.).

$\doteqdot$ University of Calcutta.

$\S$ Cold Spring Harbor.

"The Cleveland Clinic.

${ }^{\perp}$ S.S.R is a Senior Research Fellow of Council for Scientific and Industrial Research (CSIR), Govt. of India.

\# Current address: Department of Chemistry and Biochemistry, Montclair State University, Montclair, NJ 07043.

${ }^{1}$ Abbreviations: CaM, calmodulin; NO, nitric oxide; NOS, nitric oxide synthase; NOSr, reductase domain (flavoprotein + calmodulin binding site) of a given NOS. reductase domain $(15-18)$. The oxygenase and reductase domains of several NOS enzymes have been separately overexpressed in E. coli, and this has facilitated the detailed study of their structure and function (19-28).

Discovery of a fruit fly NOS in Drosophila melanogaster (dNOS) provided the first evidence that invertebrates produce NO (29). The dNOS is known to participate in essential developmental and behavioral aspects of the fruit fly, such as imaginal disc development, synaptogenesis, formation of retinal projection pattern, larval development, and response to hypoxia (30-33). It also participates in the host defense response against bacterial pathogens $(34,35)$. Despite its important roles, little is known regarding the regulation of dNOS catalysis. The enzyme is reversibly activated by $\mathrm{Ca}^{2+}$ dependent $\mathrm{CaM}$ binding $(20,36)$, as in mammalian endothelial (eNOS) and neuronal (nNOS) NOS. The overall dNOS protein sequence is $43 \%, 40 \%$, and $39 \%$ identical to the mammalian neuronal (nNOS), endothelial (eNOS), and inducible (iNOS) NOS, respectively, consistent with a relatively early divergence during evolution (Figure 1). However, the sequence of various protein regions that bind Arg, NADPH, flavin, and heme redox cofactors or form the dimer interface are highly conserved, and the dNOS enzyme contains regulatory insert peptides that are also present in mammalian eNOS and nNOS (Figure S1, Supporting Information) $(18,29,36)$, implying that there is a good conservation of enzyme function and regulation. A more detailed characterization of dNOS might contribute to our under- 


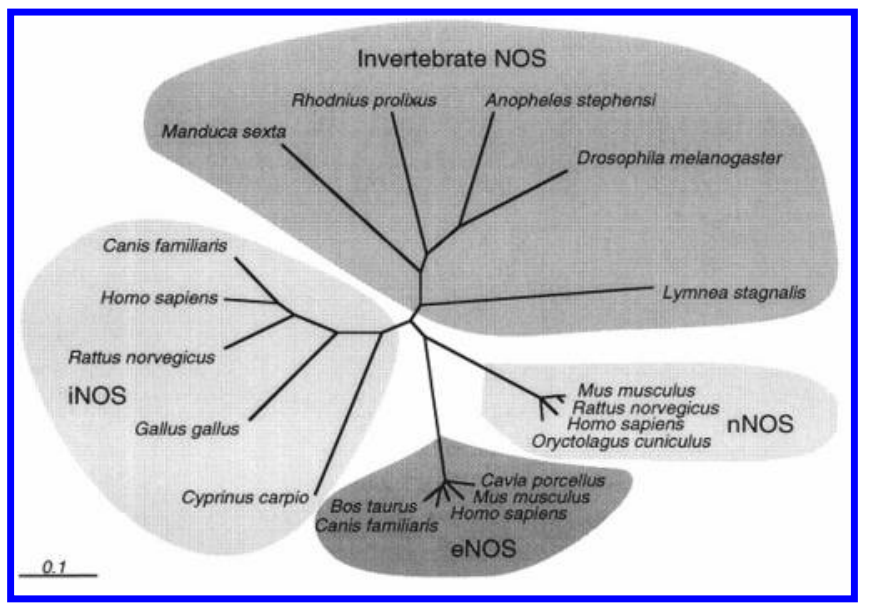

FIGURE 1: Phylogenetic tree for NOS family members. Multiple sequence alignment was performed with ClustalX (ftp://ftpigbmc. ustrasbg.fr/pub/ClustalX/) using default parameters and by drawing a tree based on exclusion of gaps, and with correction for multiple substitutions. Plots were prepared using NJPlot, taking the Lymnea stagnalis (T31080) NOS as an outgroup, and then formatted as a rootless tree using Treeview (Page, R. (1996) University of Glasgow). Major NOS groups are shaded. Full-length sequences were aligned for nNOS: Oryctolagus cuniculus (AAB68663), $H$. sapiens (P29475), Rattus norvegicus (P29476), and Mus musculus (JN0609); eNOS: Cavia porcellus (AAD29753), M. musculus (S71424), H. sapiens (A47501), Bos taurus (A38943), Canis familiaris (AAD5216); iNOS: Cyprinus carpio (CAB60197), Gallus gallus (Q90703), Rattus norvegicus (BAA020), Canis familiaris (AAC7863), and H. sapiens (A49676).

standing of its function in fruit flies and to the evolution of NOS in vertebrates and invertebrates. Unfortunately, the dNOS enzyme has proved difficult to overexpress, and an initial characterization showed that dNOS expressed in E.coli had very low reductase and NO synthase activities relative to the mammalian enzymes (36).

To overcome this issue, we created a DNA construct that codes for the reductase domain and the CaM binding site of dNOS (dNOSr) and successfully overexpressed dNOSr in E. coli. This article characterizes the purified dNOSr regarding its catalysis, kinetics, and regulation, and compares the properties of dNOSr with those of the mammalian nNOSr and eNOSr enzymes.

\section{EXPERIMENTAL PROCEDURES}

General Materials and Methods. All reagents and materials were obtained from Sigma, Alexis Biochemicals, Amersham Biosciences, or other sources as previously reported (37). General experimental methods and equipment used were as previously reported (37), unless noted otherwise.

dNOSr Construct Generation. The dNOSr starts at Arg634 and ends at Pro1350. To generate the translation start site and to introduce a hexa-His tag upstream of Arg634, the following primers were used to amplify a fragment of dNOS cDNA. 5'-CACATATGCACCACCACCACCACCACCGTGGCGAGAGCAAGGGC-3' and 5' - CTTCATGAACTCCTGCCGCGAGCTGGCCTTCATAAAGG-3'. The first primer contains a translation initiation codon (bold) within a NdeI restriction site (underlined) that was used later for the final cloning step. The second primer covers an area of dNOS cDNA that contains two BspHI sites (underlined). The second of these sites was mutated (bold) so that the first site could be used for the final cloning step. This mutation ( $\mathrm{C}$ to $\mathrm{T}$ ) did not change the coding capacity of the codon (Phe).

This PCR product was subcloned into pCR-4 vector (Invitrogen). Three fragments were isolated for the final cloning step: the $1.8 \mathrm{~kb} \mathrm{BspHI} /$ HindIII fragment of dNOS, the $0.45 \mathrm{~kb} \mathrm{NdeI} / \mathrm{BspHI}$ fragment from the pCR-4 clone described above, and the $5.5 \mathrm{~kb}$ target vector $\mathrm{pCW}$ ori that was digested with NdeI and HindIII. Positive clones of dNOSr were identified by restriction analysis.

Expression and Purification of the dNOSr Domain. The dNOSr proteins were expressed in recombinant E.coli BL21 cells. Transformed bacteria were grown at $37{ }^{\circ} \mathrm{C}$ in $3 \mathrm{~L}$ of terrific broth supplemented with $100 \mathrm{mg} / \mathrm{L}$ ampicillin. Protein expression was induced when the cultures reached an $\mathrm{OD}_{600}$ of 0.8 to 1 by adding $1 \mathrm{mM}$ isopropyl- $\beta$-D-thiogalactoside. After further growth at room temperature for $24 \mathrm{~h}$, the cells were harvested and resuspended in buffer A (40 mM EPPS, $250 \mathrm{mM} \mathrm{NaCl}$, and $10 \%$ glycerol) containing $1 \mathrm{mM}$ EDTA, $0.5 \mathrm{mg} / \mathrm{mL}$ each of leupeptin and pepstatin, $1 \mathrm{mg} / \mathrm{mL}$ lysozyme, and phenylmethylsulfonyl fluoride. Cells were lysed by freeze-thawing three times in liquid nitrogen followed by sonication for five 45-s pulses with 1-min rest on ice between pulses. The cell lysate was centrifuged at 4 ${ }^{\circ} \mathrm{C}$ for $30 \mathrm{~min}$, and the cell-free supernatant was precipitated by adding $50 \%(\mathrm{w} / \mathrm{v})$ ammonium sulfate. The precipitant was centrifuged at $4{ }^{\circ} \mathrm{C}$ for $30 \mathrm{~min}$ at $16,000 \mathrm{rpm}$. The ammonium sulfate precipitate was resuspended in buffer A containing $1 \mathrm{mM}$ phenylmethylsulfonyl fluoride, $5 \mathrm{mM} \beta$-mercaptoethanol, $2 \mu \mathrm{M}$ FAD, and $2 \mu \mathrm{M}$ FMN. The resuspended solution was loaded onto a Ni-NTA-Sepharose CL-4B column that had been charged with $50 \mathrm{mM} \mathrm{NiSO}_{4}$ and equilibrated with buffer A containing $1 \mathrm{mM}$ phenylmethylsulfonyl fluoride (PMSF), $5 \mathrm{mM} \beta$-mercaptoethanol, $2 \mu \mathrm{M}$ FAD, and 2 $\mu \mathrm{M}$ FMN. The column was washed with 5 times of equilibration buffer and 5 times of equilibration buffer containing $20 \mathrm{mM}$ imidazole. The dNOSr protein was eluted with 100 $\mathrm{mM}$ imidazole in buffer A. The eluted protein sample was immediately brought to a final concentration of $2 \mathrm{mM} \mathrm{CaCl}_{2}$ and applied to a column of CaM-Sepharose pre-equilibrated with Buffer A plus $2 \mathrm{mM} \mathrm{CaCl}$. The bound protein was washed extensively with the equilibration buffer and then eluted with Buffer A containing 3 mM EDTA. The resulting protein sample was concentrated, dialyzed against buffer A to remove the EDTA, and stored frozen in aliquots at $-80{ }^{\circ} \mathrm{C}$.

Determination of Bound FAD and FMN. Bound FAD and FMN were released from dNOSr proteins by heat denaturation of the enzyme $\left(95^{\circ} \mathrm{C}\right.$ for $5 \mathrm{~min}$ in the dark). It is essential to use well-sealed vials for this procedure in order to avoid the loss of sample volume. Subsequently, samples were cooled to $4{ }^{\circ} \mathrm{C}$ and filtered to remove denatured protein. Samples were injected into a Hewlett-Packard ODS Hypersil $5-\mu \mathrm{m} 100 \times 21-\mathrm{mm} \mathrm{C} 18$ column, equipped with a C18 guard column, equilibrated with a buffer containing $10 \%$ acetonitrile (solvent $\mathrm{A}$ ) and $90 \% 25 \mathrm{mM}$ potassium dihydrogen phosphate at $\mathrm{pH} 5.8$ (solvent B). The flavins were eluted by washing the column with the equilibration buffer mixture (10\% solvent $\mathrm{A}$ and $90 \%$ solvent $\mathrm{B})$ and then increasing solvent B from $10 \%$ to $20 \%$ in the next $20 \mathrm{~min}$. FAD and FMN had retention times of 6.8 and $9.6 \mathrm{~min}$, and the peaks were completely resolved. Flavins were detected by fluo- 
rescence emission and quantitated on the basis of authentic freshly prepared FAD and FMN standards.

Reduction of External Electron Acceptors. Wavelengths and extinction coefficients used to quantitate the NADPHdependent reduction of cytochrome $c$ and ferricyanide were $550 \mathrm{~nm}\left(20.6 \mathrm{mM}^{-1} \mathrm{~cm}^{-1}\right)$ and $420 \mathrm{~nm}\left(1.2 \mathrm{mM}^{-1} \mathrm{~cm}^{-1}\right)$, respectively (38). The composition of the assay mixture was $40 \mathrm{mM}$ EPPS at pH 7.6, $4 \mu \mathrm{M}$ FAD, $4 \mu \mathrm{M}$ FMN, $0.1 \mathrm{mg} /$ $\mathrm{mL}$ bovine serum albumin, $10 \mu \mathrm{g} / \mathrm{mL}$ CaM, $0.6 \mathrm{mM}$ EDTA, 10 units $/ \mathrm{mL}$ catalase, 10 units $/ \mathrm{mL}$ superoxide dismutase, and cytochrome $c$ or ferricyanide at 0.1 or $1 \mathrm{mM}$, respectively. In some cases, $0.83 \mathrm{mM} \mathrm{Ca}^{2+}$ was added to promote $\mathrm{CaM}$ binding to dNOSr. After the addition of dNOSr, the reaction was initiated by adding $0.1 \mathrm{mM}$ NADPH.

NADPH Oxidation. The initial rate of NADPH oxidation at $25{ }^{\circ} \mathrm{C}$ was quantitated spectrophotometrically at $340 \mathrm{~nm}$ using an extinction coefficient of $6.22 \mathrm{mM}^{-1} \mathrm{~cm}^{-1}$ (38). The dNOSr $(\sim 25 \mathrm{nM})$ was added to a cuvette containing $40 \mathrm{mM}$ EPPS (pH 7.6), $15 \mu \mathrm{g} / \mathrm{mL} \mathrm{CaM}, 0.62 \mathrm{mM} \mathrm{CaCl}_{2}, 4 \mu \mathrm{M}$ each of FAD, and FMN, 100 units $/ \mathrm{mL}$ catalase to give a final volume of $0.75 \mathrm{~mL}$. The reaction was started by adding $\mathrm{NADPH}$ to give $0.2 \mathrm{mM}$.

Measurement of Apparent $K_{m}$ for NADPH. Apparent $K_{\mathrm{m}}$ value of dNOSr was determined in the presence or absence of bound $\mathrm{CaM}$ by assays of cytochrome $c$ reductase activity measured at $550 \mathrm{~nm}$ in cuvettes. Assays were run at $25^{\circ} \mathrm{C}$ in $40 \mathrm{mM}$ EPPS (pH 7.6), containing $4 \mu \mathrm{M} \mathrm{FAD}, 4 \mu \mathrm{M}$ FMN, $0.1 \mathrm{mg} / \mathrm{mL}$ BSA, $70 \mu \mathrm{M}$ cytochrome $c, 0.6 \mathrm{mM}$ EDTA or $0.8 \mathrm{mM} \mathrm{Ca}^{2+}$ and $0.1 \mu \mathrm{M} \mathrm{CaM}$, and variable concentrations of NADPH $(0.5-15 \mu \mathrm{M})$. Reactions were started by adding $1.5 \mathrm{nM}$ enzyme in $1 \mathrm{~mL}$ final volume. Data were fitted to the Michaelis-Menten equation using the software Origin, version 6.1.

Fluorescence Spectroscopy. Tryptophan fluorescence emission was measured using a Hitachi model spectrofluorometer. A $1 \mathrm{~mL}$ quartz cuvette with a path length of $1 \mathrm{~cm}$ was used for the experiments. Dilution effects were less than $0.5 \%$, and the samples were maintained at $28{ }^{\circ} \mathrm{C}$ during measurement. The dNOSr proteins were diluted to $2 \mu \mathrm{M}$ in $40 \mathrm{mM}$ EPPS (pH 7.4), containing 0.6 mM EDTA, and $3 \mu \mathrm{M} \mathrm{CaM}$. Measurements were initiated by irradiating the protein with 290-300 nm light. Emission spectra were recorded between 300 and $450 \mathrm{~nm}$ before and after the addition of $1 \mathrm{mM} \mathrm{CaCl}_{2}$ to induce $\mathrm{CaM}$ binding to $\mathrm{dNOSr}$ and the addition of $3 \mathrm{mM}$ EDTA to induce dissociation of CaM. Control experiments that omitted either dNOSr protein or calmodulin were also run. Flavin fluorescence measurements were done under identical conditions except that the proteins were irradiated with 450-460 nm light, and their emission spectra were recorded between 450 and $700 \mathrm{~nm}$. In some experiments, flavin and tryptophan fluorescence emission at 530 and $340 \mathrm{~nm}$, respectively, was monitored over time before and after the addition of $\mathrm{CaCl}_{2}$ or EDTA. In most experiments, aliquots were withdrawn from the cuvette at various time points for the measurement of cytochrome $c$ reductase activity.

Anaerobic Stopped-flow Flavin Reduction Kinetics. Stoppedflow rapid scan analysis of flavin reduction by excess NADPH was performed under anaerobic conditions at $10{ }^{\circ} \mathrm{C}$ using a TgK Ltd. SF-61 apparatus with diode-array detection. Single wavelength data was obtained using a TgK Ltd. SF-51MX equipped with photomultiplier detection. The absorbance changes associated with dNOSr flavin reduction by NADPH were recorded by rapidly mixing a solution of oxidized dNOSr $(6-10 \mu \mathrm{M})$ containing either EDTA $(1 \mathrm{mM})$ or $\mathrm{CaCl}_{2}(2 \mathrm{mM})+\mathrm{CaM}(20-25 \mu \mathrm{M})$ with a solution of 60-100 $\mu \mathrm{M}$ NADPH (excess NADPH). The maximum absorbance value for a given protein sample at $457 \mathrm{~nm}$ during single wavelength experiments was obtained by replacing the NADPH solution in one of the stopped-flow syringes with buffer only and recording additional mixing events. Absorbance changes at 457 and $600 \mathrm{~nm}$ were averaged from 6 to 10 individual reactions and were fit to single or multiple exponential functions using software provided by the instrument manufacturer as indicated in the text. Percent absorbance changes were calculated for the absorbance change occurring in the instrument dead time $(1.5 \mathrm{~ms})$ and for each kinetic phase as the ratio between the total absorbance change and the relative absorbance changes obtained from the fitting program.

Anaerobic Pre-Steady-State Cytochrome c Reduction. A solution of dNOSr $(16 \mu \mathrm{M})$, glycine $(3 \mathrm{mM})$, 5-deazariboflavin (catalytic amount), and either EDTA $(1 \mathrm{mM})$ or $\mathrm{CaCl}_{2}$ $(2 \mathrm{mM})+\mathrm{CaM}(30 \mu \mathrm{M})$ was completely photoreduced at 4 ${ }^{\circ} \mathrm{C}$ in an anaerobic cuvette using a commercial slide projector bulb. The pre-reduced protein sample was rapidly mixed with a solution of cytochrome $c(3 \mu \mathrm{M})$ at $10{ }^{\circ} \mathrm{C}$ in a stoppedflow spectrophotometer, and the absorbance change at $550 \mathrm{~nm}$ was recorded. In some cases, $1 \mathrm{mM}$ NADPH was added to the pre-reduced protein sample, and the mixture was incubated at $10{ }^{\circ} \mathrm{C}$ for $15 \mathrm{~min}$ prior to mixing. Absorbance data were fit to a single-exponential function.

Oxidation of Reduced dNOSr. A solution of dNOSr protein $(3.5 \mu \mathrm{M})$ containing either EDTA $(1 \mathrm{mM})$ or $\mathrm{CaCl}_{2}(2 \mathrm{mM})$ $+\mathrm{CaM}(20 \mu \mathrm{M})$ in air-saturated buffer was reduced by adding NADPH $(80 \mu \mathrm{M})$ and then allowed to autoxidize at room temperature in an open cuvette while following the process at $457 \mathrm{~nm}$ and recording visible spectra at different points during the experiment.

\section{RESULTS AND DISCUSSION}

Expression and Purification of dNOSr. The fruit fly gene encoding dNOS consists of 19 exons and is dispersed over $34 \mathrm{~kb}$ of the genomic DNA (39). Alternative splicing and initiation of transcription from different start sites is common in Drosophila and ultimately may produce various enzymatically inactive proteins $(39,40)$. This ambiguity may explain the difficulties we have encountered in overexpressing dNOS in a heterologous system for biochemical studies and may explain the low reductase (Table 1) and NO synthesis (36) activities of the purified dNOS protein.

Our alternative strategy was to overexpress and study the separate reductase and oxygenase domains of dNOS, as has been done successfully for a number of NOS enzymes (40, 41). We successfully expressed dNOSr in E. coli and purified the protein to $95 \%$ homogeneity by sequential chromatography on Ni-NTA and CaM affinity resins (data not shown). The typical yield of purified protein was 5 to $6 \mathrm{mg} / \mathrm{L}$ culture. Its apparent molecular mass of $\sim 81 \mathrm{kDa}$ was in good agreement with the predicted size of the polypeptide based on the DNA sequence. The dNOSr was bright yellow indicating that oxidized flavins were bound, and HPLC analysis confirmed that two flavin molecules were bound 
Table 1: Steady-State Catalytic Activities of dNOSr and Related NOS Enzymes ${ }^{a}$

\begin{tabular}{|c|c|c|c|c|c|c|}
\hline \multirow[b]{2}{*}{ protein } & \multicolumn{2}{|c|}{$\begin{array}{l}\text { cytochrome } c \text { reduction } \\
\left(\min ^{-1}\right)\end{array}$} & \multicolumn{2}{|c|}{$\begin{array}{l}\text { ferricyanide reduction } \\
\qquad\left(\min ^{-1}\right)\end{array}$} & \multicolumn{2}{|c|}{$\begin{array}{l}\text { NADPH oxidation } \\
\left(\mathrm{min}^{-1}\right)\end{array}$} \\
\hline & $+\mathrm{CaM}$ & $-\mathrm{CaM}$ & $+\mathrm{CaM}$ & $-\mathrm{CaM}$ & $+\mathrm{CaM}$ & $-\mathrm{CaM}$ \\
\hline $\mathrm{dNOSr}$ & $2356 \pm 32$ & $644 \pm 9$ & $8249 \pm 288$ & $4449 \pm 210$ & $48 \pm 2$ & $15 \pm 2$ \\
\hline $\mathrm{dNOS}^{b}$ & 7 & 1 & 74 & 51 & NA & NA \\
\hline nNOSr & $3930 \pm 202$ & $455 \pm 9$ & $2900 \pm 201$ & $1505 \pm 29$ & $80 \pm 5$ & $5 \pm 2$ \\
\hline $\mathrm{eNOSr}^{c}$ & 125 & 64 & 225 & NA & NA & NA \\
\hline
\end{tabular}

${ }^{a}$ Assays for dNOSr or nNOSr were run at room temperature. Activities are the mean of at least four trials \pm SD. Values taken from the literature were also recorded at room temperature, but the SDs, if available, were omitted. NA, not available. ${ }^{b}$ Sengupta et al., ref $36 .{ }^{c}$ Ghosh et al., ref 59 .

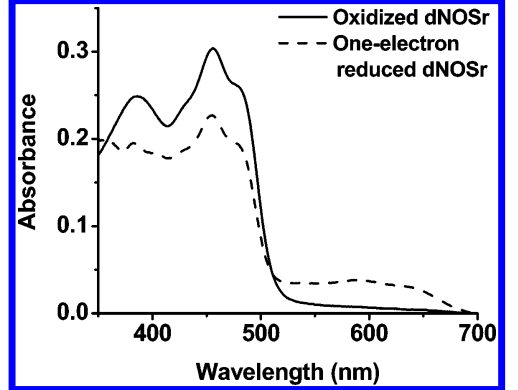

FIGURE 2: UV-visible spectra of oxidized and one-electron reduced dNOSr.

per mol of enzyme (data not shown). The absorption spectra of dNOSr as purified contained two maxima at 385 and $457 \mathrm{~nm}$ with a shoulder at $485 \mathrm{~nm}$ (Figure 2). The absence of a broad absorbance peak near $600 \mathrm{~nm}$ indicates that the dNOSr was fully oxidized after the purification procedure. The addition of a small amount of either NADPH or sodium dithionite under aerobic conditions caused a partial loss of absorbance at $457 \mathrm{~nm}$ and the appearance of a broad absorbance peak near $600 \mathrm{~nm}$, which remained stable for a long period of time in the presence of air (Figure 2). This indicates that dNOSr forms an air-stable flavin semiquinone as in the mammalian NOS reductases and in most flavoproteins of this class (42).

Reductase Activities. We measured the NADPH-dependent reductase activities of dNOSr toward the acceptors cytochrome $c, \mathrm{FeCN}_{6}$, and $\mathrm{O}_{2}$. For five dNOSr preparations, the rates of cytochrome $c$ reduction decreased less than $10 \%$ in the absence of added FMN and FAD (data not shown), confirming that the isolated protein is flavin-replete. Table 1 reports the basal and CaM-stimulated activities of $\mathrm{dNOSr}$ and compares them to the activities of nNOSr and the reported activities of $\mathrm{dNOS}$ and eNOSr. The reductase activities of dNOSr were most similar to mammalian nNOS with regard to their magnitude and were much greater than the activities of mammalian eNOS (43). The dNOSr reductase activities displayed the same rank order toward the three electron acceptors as do the mammalian NOS reductases, in that they all transfer electrons to ferricyanide most rapidly, followed by cytochrome $c$, and then dioxygen. The activities of dNOSr were much greater than those previously reported for the bacterially expressed full-length dNOS (36). Our current data suggest that an earlier report of poor reductase activity for dNOS (36) was probably due to a problem expressing a fully active form of the full-length enzyme.

The dNOSr showed an approximate 4-fold rate enhancement for cytochrome $c$ reduction upon $\mathrm{CaM}$ binding, while for ferricyanide and $\mathrm{O}_{2}$ reduction, the rate of enhancement was about 2- and 3-fold, respectively. This confirms that

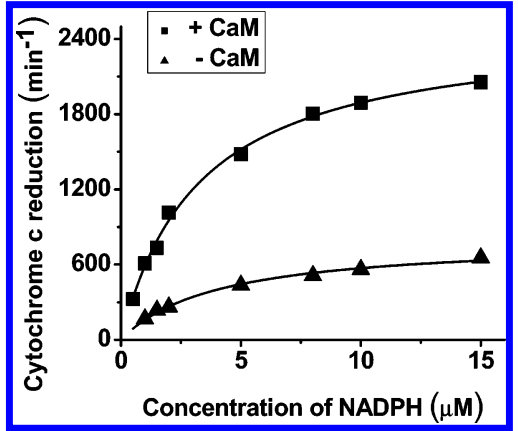

FIGURE 3: Apparent $K_{\mathrm{m}}$ for NADPH in CaM-bound and -free dNOSr. Cytochrome $c$ reductase activities of CaM-free or CaMbound dNOSr were measured at room temperature for each indicated NADPH concentration. The data were fit to the Michaelis-Menten equation to obtain apparent $K_{\mathrm{m}}$ values. Reactions were run in triplicate.

dNOS is CaM-responsive (36) in a manner generally similar to the mammalian nNOS and eNOS enzymes and shows that dNOSr achieves about half the gain in activity that one observes when CaM binds to nNOSr (Table 1) $(43,44)$. In general, the data show that (i) dNOSr has much greater reductase activity than what was previously reported for dNOS (36) and that (ii) dNOSr is catalytically more similar to nNOS than to eNOS.

Apparent $K_{m}$ for $N A D P H$. We determined an apparent $K_{\mathrm{m}}$ value for NADPH by measuring the initial cytochrome $c$ reductase activity of dNOSr over a range of NADPH concentrations both in the presence and absence of bound CaM (Figure 3). This gave apparent $K_{\mathrm{m}}$ values for NADPH of $4.1 \pm 0.1$ and $3.2 \pm 0.2 \mu \mathrm{M}$ in the CaM-free and CaMbound dNOSr, respectively. These values are similar to those determined for mammalian NOS enzymes under similar experimental conditions $(45,52)$.

CaM Binding to dNOSr. We measured cytochrome $c$ reductase activities to determine the $\mathrm{Ca}^{2+}$ concentration required for $\mathrm{CaM}$ binding to $\mathrm{dNOSr}$. The relationship between reductase activity and the free $\mathrm{Ca}^{2+}$ concentration is shown in Figure 4. The half-maximal increase in activity (EC50) was achieved at between 100 and $150 \mathrm{nM}$ free $\mathrm{Ca}^{2+}$ concentration, while maximum activity was attained at 500 to $1000 \mathrm{nM}$ free $\mathrm{Ca}^{2+}$ concentration. In comparison, the EC50 value we obtained for nNOSr in identical experiments was 150-200 nM free $\mathrm{Ca}^{2+}$ and for eNOSr was 80$100 \mathrm{nM}$ free $\mathrm{Ca}^{2+}$ (data not shown) (46). These data confirm that CaM binding to dNOS may require intracellular $\mathrm{Ca}^{2+}$ concentrations to increase above the resting level in cells, consistent with dNOS functioning in cell signaling cascades $(9,47)$. The data also suggest that CaM binding to dNOSr may require a free $\mathrm{Ca}^{2+}$ concentration that lies between the concentrations required by nNOS and eNOS. However, it is 


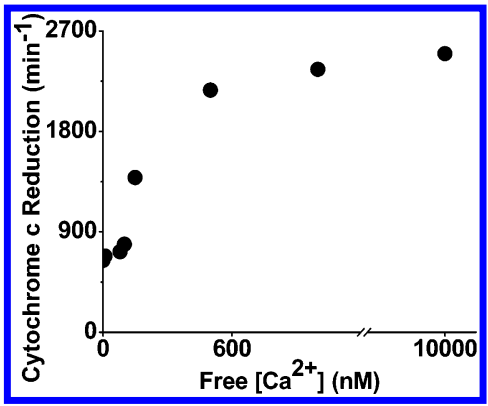

FIGURE 4: $\mathrm{Ca}^{2+}$ concentration dependence for $\mathrm{CaM}$ binding to dNOSr. Cytochrome $c$ reductase activity of dNOSr was measured at room temperature in the presence of $\mathrm{CaM}$ and at the indicated free $\mathrm{Ca}^{2+}$ concentrations. Data points are the mean of three measures and are representative of two trials.
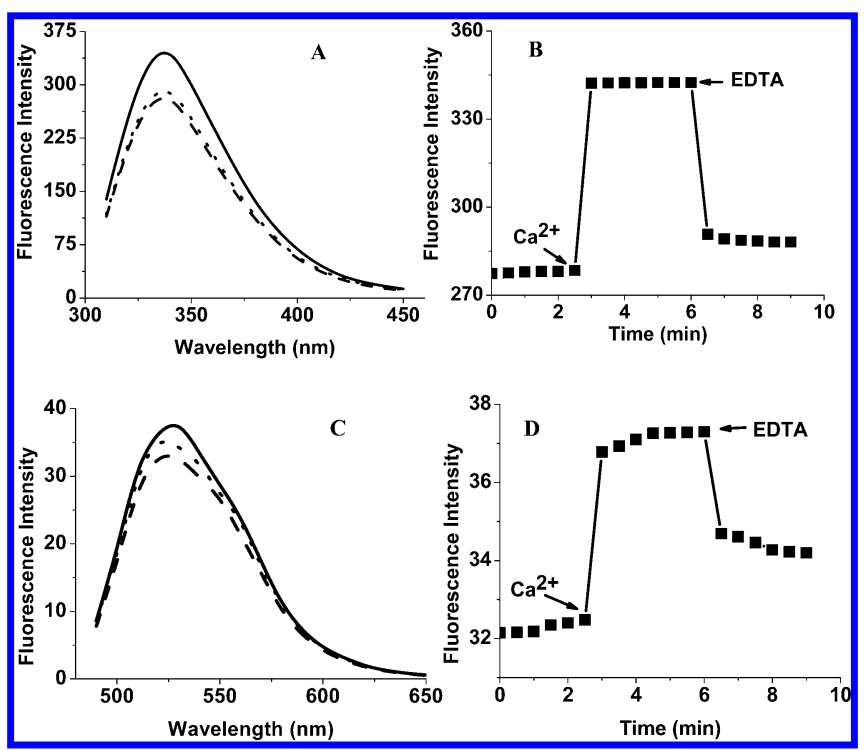

FIGURE 5: Effect of $\mathrm{CaM}$ on dNOSr tryptophan and flavin fluorescence. Cuvettes contained dNOS, CaM, and EDTA in buffer. Panels A and B show tryptophan fluorescence emission in samples before $\mathrm{CaM}$ binding $(-)$, after the addtion of $\mathrm{Ca}^{2+}$ to promote $\mathrm{CaM}$ binding (---), and after the addition of excess EDTA to dissociate $\mathrm{CaM}$ from the protein $(\cdots)$. The sample spectra were recorded at room temperature 10 min after each addition. Panels $C$ and $D$ show flavin fluorescence emission in samples undergoing the same procedures described above. Data are representative of three identical experiments.

important to note that the N-terminal hexa-His tag that we incorporated for aiding protein purification lies next to the CaM binding motif, and so could conceivably affect the $\mathrm{Ca}^{2+}$ dependence of dNOSr.

To investigate if $\mathrm{CaM}$ binding causes protein conformational change in dNOSr, we monitored the tryptophan and flavin fluorescence upon $\mathrm{CaM}$ binding to fully oxidized dNOSr. CaM binding to dNOSr increased both its tryptophan and flavin fluorescence (Figure 5). This is identical to the behavior of nNOSr in similar experiments $(38,41)$. In the case of dNOSr tryptophan fluorescence, the increase was almost fully reversed upon the addition of EDTA, which by chelating $\mathrm{Ca}^{2+}$ should cause $\mathrm{CaM}$ to dissociate. Indeed, this was confirmed by our observation of an expected increase and decrease in cytochrome $c$ reductase activity in sample aliquots removed at the appropriate time points (data not shown). Unlike tryptophan fluorescence, the increase in dNOSr flavin fluorescence was not fully reversed upon EDTA addition, despite the cytochrome $c$ reductase activity measurements showing that EDTA caused a complete return

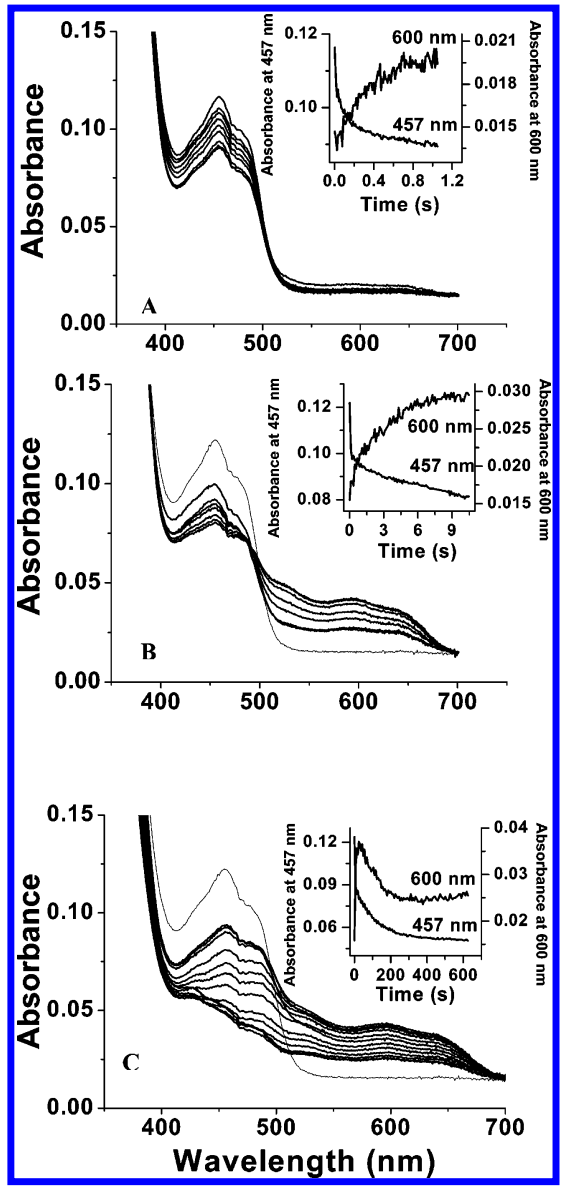

FIGURE 6: Kinetics of NADPH-dependent flavin reduction in dNOSr. Stopped-flow data were collected during anaerobic reduction of oxidized dNOSr by a 10-fold molar excess of NADPH at $10{ }^{\circ} \mathrm{C}$. Panels A, B, and C contain rapid-scan diode array spectra collected over 1,10 , and $584 \mathrm{~s}$ of the reaction, respectively. Insets show the time course of absorbance change at 457 and $600 \mathrm{~nm}$. Data are representative of three similar experiments.

to basal reductase activity (data not shown). This behavior is reminiscent of nNOSr (41), and may indicate some small loss of bound flavins into solution or a return to a somewhat different distribution of conformational states upon the dissociation of CaM. Regardless, the fluorescence data strongly suggest that dNOSr is subject to a protein conformational equilibrium as described for nNOSr that involves solvent-shielded and deshielded conformational states of the FMN module and can be reversibly shifted toward the FMNdeshielded state by CaM binding $(37,50)$. This shift in the conformational equilibrium is thought to explain how $\mathrm{CaM}$ increases the cytochrome $c$ reductase activity of nNOSr, and our data with dNOSr provide additional support for this hypothesis.

Kinetics of NADPH-Mediated Flavin Reduction. Flavin reduction was studied under anaerobic conditions at $10^{\circ} \mathrm{C}$ by mixing the oxidized dNOSr protein with excess NADPH in a stopped-flow spectrophotometer that was equipped with either a diode array or single wavelength detector. Absorbance changes at 457 and $600 \mathrm{~nm}$ were monitored to follow the kinetics of flavin reduction. Sets of rapid scan spectra that record the reduction process over increasingly broad time periods are shown in Figure 6. Reduction of dNOSr by NADPH was best described as a triphasic process that took nearly $400 \mathrm{~s}$ to complete under these conditions. The first phase of the reaction occurred within $1 \mathrm{~s}$ and involved about 
$40 \%$ of the total absorbance decrease at $457 \mathrm{~nm}$ (Figure 6, panel A). This phase was accompanied by only a small absorbance increase in the $500-700 \mathrm{~nm}$ region, suggesting that it involved mainly the hydride transfer from NADPH to FAD with little subsequent electron transfer from the FAD hydroquinone to FMN. The second phase of the reaction was distinguished by a significant absorbance gain in the 500$700 \mathrm{~nm}$ region that continued for about $18 \mathrm{~s}$ until it started to decrease (Figure 6, panel B). In nNOSr or other related flavoproteins, an absorbance increase in the 500-700 nm region at this stage is thought to reflect inter-flavin electron transfer and buildup of flavin semiquinone species $(42,48)$. Subsequently, we observed a third phase that involved a further loss of absorbance at $457 \mathrm{~nm}$ and at $600 \mathrm{~nm}$ (Figure 6, panel C), which likely corresponds to the further reduction of the flavin semiquinone species by a second molecule of NADPH and also likely involves some electronic disproportionation between enzyme molecules in solution.

In general, the reduction of mammalian NOS or other related flavoproteins by NADPH begins with hydride transfer to $\mathrm{FAD}$, followed by an inter-flavin $\left(\mathrm{FADH}_{2}\right.$ to $\left.\mathrm{FMN}\right)$ electron transfer to generate protein forms containing the flavin semiquinones (49-51). Subsequent events include $\mathrm{NADP}^{+}$dissociation, binding of a second molecule of $\mathrm{NADPH}$, additional inter-flavin electron transfer, and a second hydride transfer to FAD. The initial phase of the dNOSr reduction occurred within $1 \mathrm{~s}$ and appears to mainly involve hydride transfer from NADPH to FAD with a negligible amount of inter-flavin electron transfer. The relatively slower second phase likely reflects an inter-flavin electron transfer step. It is remarkable that flavin semiquinone buildup took nearly $18 \mathrm{~s}$ to reach a maximum in dNOSr, which is very slow compared to that of mammalian NOS enzymes $(28,48,43,49)$. Further reduction of dNOSr also took a considerably longer time. For example, very similar spectral transitions were observed during the reduction of nNOSr by excess NADPH at the same temperature, but the process is almost completed within $2 \mathrm{~s}$ compared to almost $400 \mathrm{~s}$ for dNOSr $(28,48)$. In nNOSr, flavin semiquinone buildup reached a maximum within about $0.5 \mathrm{~s}$. Our data suggest that inter-flavin electron transfer during NADPH reduction of dNOSr is much slower than that in nNOSr, at least when studied in stopped-flow experiments similar to those employed here. The reason for the difference is unclear. However, it is important to note that the cytochrome $c$ reductase activities of $\mathrm{dNOSr}$ and $\mathrm{nNOSr}$ are not so different (Table 1). This implies that the speed of flavin reduction and $\mathrm{FMNH}_{2}$ formation in $\mathrm{dNOSr}$ in the presence of an electron acceptor (cytochrome $c$ ) during steady-state catalysis must be faster than what we observe in the stopped-flow study and more similar to nNOSr.

Because CaM is known to increase the rate of flavin reduction in $\mathrm{nNOSr}(42,48)$, we examined if CaM would alter the kinetics of flavin reduction in dNOSr. Our rapid scan results indicated that CaM-bound dNOSr still had a relatively slow flavin reduction process that was similar to the CaM-free condition described above (data not shown). We decided to focus more closely on the initial phase of the flavin reduction process by collecting stopped-flow traces in the first second of the reaction using a photomultiplier detector set at $457 \mathrm{~nm}$. The absorbance traces obtained during the reduction of CaM-free or CaM-bound dNOSr with excess

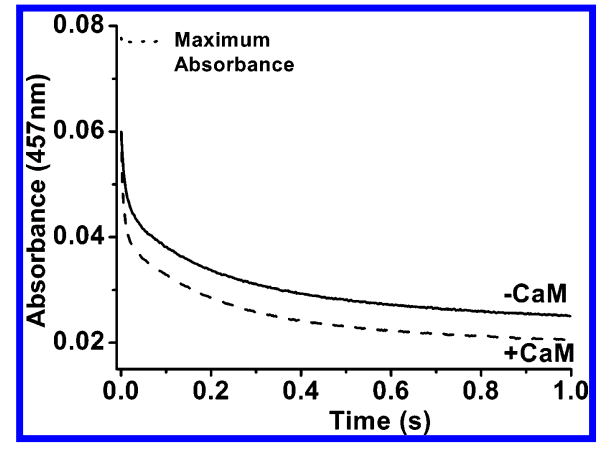

FIGURE 7: Effect of CaM on the kinetics of NADPH-dependent flavin reduction in dNOSr. Stopped flow traces were collected at $457 \mathrm{~nm}$ after rapidly mixing $7 \mu \mathrm{M}$ oxidized dNOSr with excess NADPH under anaerobic conditions at $10{ }^{\circ} \mathrm{C}$. The traces shown are an average of 6 to 7 individual scans and are representative of two independent experiments.

NADPH are shown in Figure 7. For each experiment, an initial absorbance value representing no flavin reduction was obtained to indicate the amount of the total absorbance change that takes place in the instrument mixing dead time (48). The absorbance traces recorded during the $1 \mathrm{~s}$ reactions were best fit to a triple exponential function using the process described in Experimental Procedures, and the observed rate constants are reported in Table 2. We observed a 1.8-fold stimulatory effect of CaM on rate constant $k_{1}$, whereas values for $k_{2}$ and $k_{3}$ remained essentially similar both in the presence and absence of CaM. In general, this mimics how $\mathrm{CaM}$ affects flavin reduction kinetics in nNOSr, although the degree of CaM stimulation in dNOSr is less than that observed for nNOSr under identical conditions, where $\mathrm{CaM}$ increases $k_{1}$ by 3 to 4 times and also increases the slower phases of flavin reduction $(48,51)$.

The lack of an absorbance increase at $700 \mathrm{~nm}$ during the reduction of dNOSr by NADPH indicates that a chargetransfer complex between $\mathrm{FADH}_{2}$ and $\mathrm{NADP}^{+}$did not build up in dNOSr during the stopped-flow reaction. Likewise, we found that no charge-transfer complex built up during a stepwise, equilibrium photoreduction of $\mathrm{dNOSr}$ in the presence of $\mathrm{NADP}^{+}$and in the presence or absence of $\mathrm{CaM}$ (data not shown). The inability to form a charge-transfer complex either in the pre-steady state or equilibrium condition during flavin reduction distinguishes dNOSr from nNOSr, which builds up charge-transfer complexes under both experimental settings $(42,48,52)$. This implies that the interaction between the bound $\mathrm{FADH}_{2}$ cofactor and the nicotinamide ring of $\mathrm{NADP}^{+}$differs in dNOSr compared to that in nNOSr $(45,48,52)$ and that it may be more similar to the Asp1393 point mutants of nNOSr, which do not form observable charge-transfer complexes during their reduction by NADPH $(48,52)$.

Reactivity of Reduced dNOSr Flavins with Oxygen. Oxidized samples of CaM-free or CaM-bound dNOSr were mixed with a 20-fold molar excess of NADPH in airsaturated buffer: visible spectra were collected at different time points, or alternatively, the flavin absorbance was continuously monitored with time. Figure 8 shows that dNOSr maintained a significant population of flavin semiquinone species, while NADPH was being oxidized. The CaM-bound dNOSr consumed the NADPH somewhat faster than the CaM-free enzyme and had a faster rate of flavin oxidation once the NADPH became depleted. This correlates 
Table 2: Kinetics of Flavin Reduction in $\mathrm{dNOSr}^{a}$

\begin{tabular}{cccccc}
\hline \multirow{2}{*}{ protein } & conditions & $\begin{array}{c}\text { instrument } \\
\text { dead time }\end{array}$ & $\begin{array}{c}k_{1}(\%) \\
\left(\mathrm{s}^{-1}\right)\end{array}$ & $\begin{array}{c}k_{2}(\%) \\
\left(\mathrm{s}^{-1}\right)\end{array}$ & $\begin{array}{c}k_{3}(\%) \\
\left(\mathrm{s}^{-1}\right)\end{array}$ \\
\hline $\mathrm{dNOSr}$ & $-\mathrm{CaM}$ & $23 \%$ & $70 \pm 4(33 \%)$ & $6.0 \pm 0.2(29 \%)$ & $1.2 \pm 0.1(15 \%)$ \\
& $+\mathrm{CaM}$ & $23 \%$ & $127 \pm 5(35 \%)$ & $6.4 \pm 0.9(24 \%)$ & $1.6 \pm 0.1(17 \%)$ \\
\hline
\end{tabular}

${ }^{a} \mathrm{dNOSr}$ was mixed with a 10-fold molar excess of NADPH in a stopped-flow instrument at $10^{\circ} \mathrm{C}$, and the absorbance change was recorded at $457 \mathrm{~nm}$. Rates were determined as described in Experimental Procedures. Rates are the mean \pm S.D. for $6-10$ mixing experiments. The values in parentheses are the percentage of absorbance change attributed to each kinetic phase.

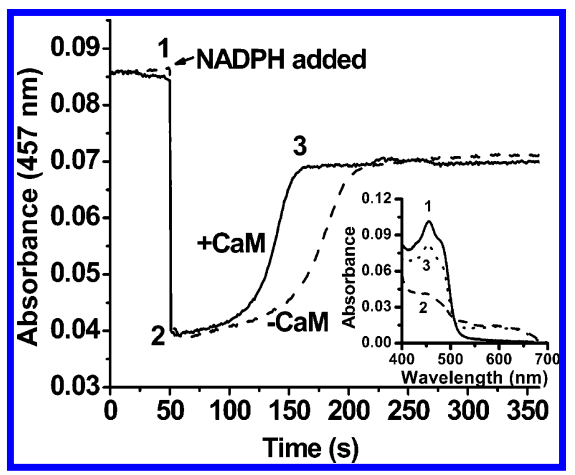

FIGURE 8: Kinetics of flavin oxidation in dNOSr. Cuvettes containing CaM-free or -bound dNOSr $(3.5 \mu \mathrm{M})$ in air-saturated buffer had a 20-fold molar excess of NADPH added at the indicated time, and the absorbance at $457 \mathrm{~nm}$ was followed over time. The inset contains visible spectra that were recorded prior to, during, and after NADPH oxidation by dNOSr at points indicated by numerals. The data shown are representative of three experiments.

well with the approximate 3-fold greater steady-state NADPH oxidase activity of CaM-bound dNOSr (Table 1). Both CaMfree or CaM-bound dNOSr samples had a similar final absorbance value at the end of the oxidation reaction indicating that their final states were the same and that they presumably contained an air-stable FMN semiquinone. These results are generally similar to those reported for nNOSr and indicate that the reduced flavins in dNOSr react relatively slowly with $\mathrm{O}_{2}$ in both the CaM-free and CaM-bound states. The data in Figure 8 gave estimated reaction rates of 10 and $15 \mathrm{~min}^{-1}$, respectively. These are about twice the rates reported for nNOSr under similar reaction conditions $(45,48)$.

Regulation of the FMN Module Conformational Equilibrium. In nNOSr, the FMN module exists in equilibrium between a shielded and a deshielded conformational state $(45,49,53)$. The FMN-shielded state is stabilized by NADPH binding, while the FMN-deshielded state is stabilized by $\mathrm{CaM}$ binding $(45,48,50,52)$. To determine if dNOSr employs a similar regulation, we utilized an established stopped-flow method $(48,50)$ to measure the degree of FMN shielding in dNOSr and the effects of NADPH and $\mathrm{CaM}$. We measured the rate of cytochrome $c$ reduction by an excess of photoreduced dNOSr protein in a stopped-flow spectrophotometer and assumed the observed rate to be proportional to the fraction of dNOSr present in the FMNdeshielded state. Thus, the reaction rate should increase or decrease depending on changes in the conformational equilibrium. Figure 9 contains representative stopped-flow traces from the different conditions used. All the absorbance traces fit well to a single-exponential function, and the rate constants obtained are given in Table 3 . The highest rate constant was measured for the NADPH- and CaM-bound $\mathrm{dNOSr}$ and the slowest for the CaM-free but NADPH-bound enzyme. This tendency is in exact accordance with previous

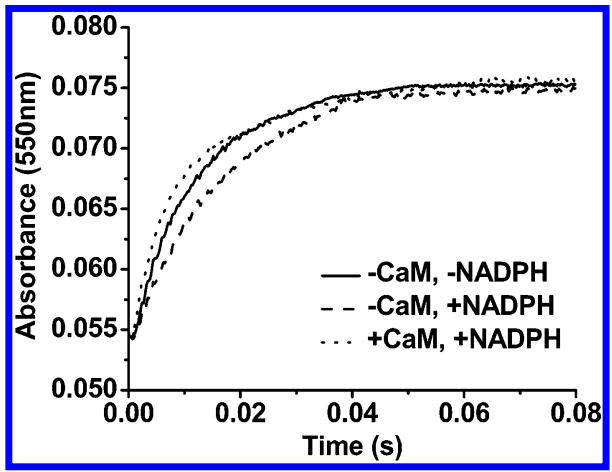

FIGURE 9: Kinetics of cytochrome $c$ reduction by excess reduced dNOSr. Enzyme was photoreduced under anaerobic conditions in the presence or absence of NADPH and CaM as indicated and then was rapidly mixed at $10{ }^{\circ} \mathrm{C}$ in a stopped flow spectrophotometer with a sub-stoichiometric amount of cytochrome $c$. Absorbance was recorded at $550 \mathrm{~nm}$. Each trace is the average of 6-8 individual reactions, and the data are representative of two independent experiments.

Table 3: Rates of Pre-Steady-State Cytochrome $c$ Reduction by $\mathrm{dNOSr}^{a}$

\begin{tabular}{cccc}
\hline protein & $\begin{array}{c}-\mathrm{CaM} \\
-\mathrm{NADPH} \\
\left(\mathrm{s}^{-1}\right)\end{array}$ & $\begin{array}{c}-\mathrm{CaM} \\
+\mathrm{NADPH} \\
\left(\mathrm{s}^{-1}\right)\end{array}$ & $\begin{array}{c}+\mathrm{CaM} \\
+\mathrm{NADPH} \\
\left(\mathrm{s}^{-1}\right)\end{array}$ \\
\hline dNOSr & $64 \pm 5$ & $34 \pm 3$ & $104 \pm 8$ \\
\hline
\end{tabular}

${ }^{a} \mathrm{dNOSr}$ enzyme $(16 \mu \mathrm{M})$ was photoreduced under anaerobic conditions and then was rapidly mixed with a sub-stoichiometric amount of cytochrome $c(3 \mu \mathrm{M})$ in a stopped-flow instrument at $10^{\circ} \mathrm{C}$. The absorbance increase at $550 \mathrm{~nm}$ was used to calculate the observed rate of electron transfer to cytochrome $c$ under the different conditions specified. The rates are the mean $\pm \mathrm{SD}$ of six to eight individual mixing experiments done with two indipendent preparations.

results for $\mathrm{nNOSr}$ in similar experiments $(48,50)$, although the magnitude of the changes observed here for dNOSr are smaller than those for nNOSr. We conclude that a similar regulatory mechanism is operative in which bound NADPH stabilizes the FMN-shielded conformation and CaM stabilizes the FMN-deshielded conformation in dNOSr. Such conformational regulation would be consistent with the flavin fluorescence results we obtained with dNOSr, which indicated that $\mathrm{CaM}$ binding caused greater solvent exposure of the FMN module.

By analogy to nNOS $(48,52)$, we speculate that the CaMinduced change in the FMN shielding equilibrium of dNOSr may be responsible for its greater cytochrome $c$ reductase activity after CaM binds. Indeed, dNOSr contains a conserved C-terminal tail regulatory element that is thought to help regulate the conformational equilibrium of the FMN module, and the tail element of dNOSr also contains a particular conserved residue (Arg1329) that in nNOS enables bound NADPH to stabilize the FMN-shielded conformation $(45,48,52)$. 
Summary and Perspectives. dNOSr is only the second CaM-regulated NOS reductase domain to be characterized at this level of detail (the other being nNOS). The similarities and differences we observed between dNOSr and the mammalian $\mathrm{nNOSr}$ regarding catalysis and regulation of electron transfer provide insight from an evolutionary and protein structure-function standpoint. For example, the ability of $\mathrm{CaM}$ and NADPH to shift the conformational equilibrium of the FMN module in opposite directions and impact the enzyme's cytochrome $c$ reductase activity in kind appears to be conserved in dNOS and nNOS. This is consistent with both enzymes conserving the protein structural elements that are thought to enable regulation, including the C-terminal tail and autoinhibitory insert (Figure S1, Supporting Information) $(18,54)$.

Given that Drosophila express only one type of NOS, all roles for NO in Drosophila including its larval development (30) and host defense $(34,35)$ must manifest through the regulation of dNOS. It makes sense that an organism would utilize a CaM-regulated NOS in signal transduction cascades that operate during development. Likewise, having a NOS enzyme whose reductase domain can support a high rate of electron transfer (as judged here by cytochrome $c$ reductase activity) may presumably enable greater rates of $\mathrm{NO}$ synthesis as required in host defense. But, it is interesting that Drosophila must rely on a $\mathrm{Ca}^{2+}$-activated NOS for host defense, whereas mammals express a $\mathrm{Ca}^{2+}$-independent NOS for this purpose (55). Our data indicate that dNOS requires $\mathrm{a} \mathrm{Ca}^{2+}$ concentration for activation by $\mathrm{CaM}$ that is between the $\mathrm{Ca}^{2+}$ concentration required by mammalian eNOS and nNOS. This suggests that dNOS might also be activated by post-translational modification, as occurs for eNOS in endothelial cells that undergo shear stress during blood circulation (56). In this circumstance, phosphorylation at a Ser residue in the C-terminal tail of eNOS shifts its $\mathrm{Ca}^{2+}$ requirement for $\mathrm{CaM}$ binding down to the resting $\mathrm{Ca}^{2+}$ level in the cell and thus activates eNOS for NO synthesis (44, 57, 58). Although dNOS does not conserve this Ser in its $\mathrm{C}$-terminal regulatory element (it has an Ala in this position; Figure S1, Supporting Information), perhaps a posttranslational modification at another site in dNOS can activate the enzyme for sustained NO release during a host defense response in Drosophila.

\section{ACKNOWLEDGMENT}

We thank members of the Stuehr and Ghosh laboratories for their assistance and advice.

\section{SUPPORTING INFORMATION AVAILABLE}

Sequence alignment of the Drosophila NOS reductase domain and other NOS sequences. This material is available free of charge via the Internet at http://pubs.acs.org.

\section{REFERENCES}

1. Griffith, O. W., and Stuehr, D. J. (1995) Nitric oxide synthases, properties and catalytic mechanism, Annu. Rev. Phvsiol. 57, 707736.

2. Marletta, M. A., Hurshman, A. R., and Rusche, K. M. (1998) Catalysis by nitric oxide synthase, Curr. Opin. Chem. Biol. 2, 656-663.

3. Hemmens, B., and Mayer, B. (1998) Enzymology of nitric oxide synthases, Methods Mol. Biol. 10, 1-32.
4. MacMicking, J., Xie, Q., and Nathan, C. (1997) Nitric oxide and macrophage function, Annu. Rev. Immunol. 15, 323-350.

5. Ignarro, L. J. E. (2000) Nitric Oxide: Biology and Pathobiology, Academic Press, San Diego, CA.

6. Furchgott, R. F. (1999) Nitric oxide: a unique endogenous signaling molecule in vascular biology, Biosci. ee. 19, 235251.

7. Muller, U. (1997) The nitric oxide system in insects, Prog. Neurobiol. 51, 363-381.

8. Adak, S., Aulak, K. S., and Stuehr, D. J. (2002) Direct evidence for nitric oxide production by a nitric-oxide synthase-like protein from Bacillus subtilis, J. Biol. Chem. 277, 16167-16171.

9. Davies, S. (2000) Nitric oxide signaling in insects, Insect Biochem. Mol. Biol. 12, 1123-1138.

10. Lin, A. W., Chang, C. C., and McCormick, C. C. (1996) Molecular cloning and expression of an avian macrophage nitric-oxide synthase cDNA and the analysis of the genomic 5'-flanking region, J. Biol. Chem. 271, 11911-11919.

11. Korneev, S. A., Piper, M. R., Picot, J., Phillips, R., Korneeva, E. I., and O'Shea, M. J. (1998) Molecular characterization of NOS in a mollusc: expression in a giant modulatory neuron, $\underline{\text { Neuro- }}$ biology 35, 65-76.

12. Ninnemann, H., and Maier, J. (1996) Indications for the occurrence of nitric oxide synthases in fungi and plants and the involvement in photoconidiation of Neurospora crassa, Photochem. Photobiol. 64, 393-398.

13. Durner, J., Wendehenne, D., and Klessig, D. F. (1998) Defense gene induction in tobacco by nitric oxide, cyclic GMP and cyclic ADP ribose, Proc. Natl. Acad. Sci. U.S.A. 95, 10328-10333.

14. Paveto, C., Pereira, C., Espinosa, J., Montagna, A. E., Farber, M., Esteva, M., Flawia, M. M., and Torres, H. N. (1995) The nitric oxide transduction pathway in Trypanosoma cruzi, J. Biol. Chem. 270, 16576-16579.

15. Abu-Soud, H. M., Loftus, M., and Stuehr, D. J. (1995) Subunit dissociation and unfolding of macrophage NO synthase: relationship between enzyme structure, prosthetic group binding, and catalytic function, Biochemistry 34, 11167-11175.

16. Stuehr, D. J, Pou, S., and Rosen, G. M. (2001) Oxygen reduction by nitric-oxide synthases, J. Biol. Chem. 276, 14533-14536.

17. Pfeiffer, S., Mayer, B., and Hemmens, B. (1999) Nitric oxide: chemical puzzles posed by a biological messenger, Angew. Chem. Int. Ed. 38, 1714-1731.

18. Roman, L. J., Martasek, P., and Masters, B. S. (2002) Intrinsic and extrinsic modulation of nitric oxide synthase activity, Chem. Rev. 102, 1179-1190.

19. Rozhkova, E. A., Fujimoto, N., Sagami, I., Daff, S. N., and Shimizu, T (2002) Interactions between the isolated oxygenase and reductase domains of neuronal nitric-oxide synthase. Assessing the role of calmodulin, J. Biol. Chem. 277, 16888-16894.

20. Ghosh, D. K., Abu-Soud, H. M., and Stuehr, D. J. (1995) Reconstitution of the second step in NO synthesis using the isolated oxygenase and reductase domains of macrophage $\mathrm{NO}$ synthase, Biochemistry 34, 11316-11320.

21. Chen, P. F., Tsai, A. L., Berka, V., and Wu, K. K. (1996) Endothelial nitric-oxide synthase. Evidence for bidomain structure and successful reconstitution of catalytic activity from two separate domains generated by a baculovirus expression system, J. Biol. Chem. 271, 14631-14635.

22. McMillan, K., and Masters, B. S. (1995) Prokaryotic expression of the heme- and flavin-binding domains of rat neuronal nitric oxide synthase as distinct polypeptides: identification of the hemebinding proximal thiolate ligand as cysteine- 415 , Biochemistry 34, 3686-3693.

23. Voegtle, H. L., Sono, M., Adak, S., Pond, A. E., Tomita, T., Perera, R., Goodin, D. B., Ikeda-Saito, M., Stuehr, D. J., Dawson, J. H. (2003) Spectroscopic characterization of five- and six-coordinate ferrous-NO heme complexes. Evidence for heme Fe-proximal cysteinate bond cleavage in the ferrous-NO adducts of the Trp409Tyr/Phe proximal environment mutants of neuronal nitric oxide synthase, Biochemistry 42, 2475-2484.

24. Feng, C., Tollin, G., Holliday, M. A., Thomas, C., Salerno, J. C., Enemark, J. H., and Ghosh, D. K. (2006) Intraprotein electron transfer in a two-domain construct of neuronal nitric oxide synthase: the output state in nitric oxide formation, Biochemistry 45, 6354-6362.

25. Garcin, E. D., Bruns, C. M., Lloyd, S. J., Hosfield, D. J., Tiso, M., Gachhui, R., Stuehr, D. J, Tainer, J. A., and Getzoff, E. D. 
(2004) Structural basis for isozyme-specific regulation of electron transfer in nitric-oxide synthase, J. Biol. Chem. 279, 3791837927.

26. Crane, B. R., Arvai, A. S., Ghosh, D. K., Wu, C., Getzoff, E. D., Stuehr, D. J., and Tainer, J. A. (1998) Structure of nitric oxide synthase oxygenase dimer with pterin and substrate, Science 279 , $2121-2126$

27. Rousseau, D. L., Li, D., Couture, M., and Yeh, S. R. (2005) Ligand-protein interactions in nitric oxide synthase, J. Inorg. Biochem. 99, 306-323.

28. Knight, K., Scrutton, N. S. (2002) Stopped-flow kinetic studies of electron transfer in the reductase domain of neuronal nitric oxide synthase: re-evaluation of the kinetic mechanism reveals new enzyme intermediates and variation with cytochrome P450 reductase, Biochem J. 367, 19-30.

29. Regulski, M., and Tully, T. (1995) Molecular and biochemical characterization of dNOS: a Drosophila $\mathrm{Ca} 2+/$ calmodulin dependent nitric oxide synthase, Proc. Natl. Acad. Sci. U.S.A. 92 , 9072-9076.

30. Kuzin, B., Roberts, I., Peunova, N., and Enikolopov, G. (1996) Nitric oxide regulates cell proliferation during Drosophila development, Cell 87, 639-649.

31. Gibbs, S. M., and Truman, J. W. (1998) Nitric oxide and cyclic GMP regulate retinal patterning in the optic lobe of Drosophila, Neuron 20, 83-93.

32. Wingrove, J. A., and O'Farrell, P. H. (1999) Nitric oxide contributes to behavioral, cellular, and developmental responses to low oxygen in Drosophila, Cell 98, 105-114.

33. Wildemann, B., and Bicker, G. (1999) Nitric oxide and cyclic GMP induce vesicle release at Drosophila neuromuscular junction, $\underline{J}$. Neurobiol. 39, 337-346.

34. Nappi, A. J., Vass, E., Frey, F., and Carton, Y. (2000) Nitric oxide involvement in Drosophila immunity, Nitric Oxide 4, 423-430.

35. McGettigan, J., McLennan, R. K., Broderick, K. E., Kean, L., Allan, A. K., Cabrero, P., Regulski, M. R., Pollock, V. P., Gould, G. W., Davies, S. A., and Dow, J. A. (2005) Insect renal tubules constitute a cell-autonomous immune system that protects the organism against bacterial infection, Insect. Biochem. Mol. Biol. $35,741-754$

36. Sengupta, R., Sahoo, R., Mukherjee, S., Regulski, M., Tully, T., Stuehr, D. J., and Ghosh, S. (2003) Characterization of Drosophila nitric oxide synthase: a biochemical study, Biochem. Biophys. Res. Commun. 306, 590-597.

37. Konas, D. W., Zhu, K., Sharma, M., Aulak, K. S., Brudvig, G. W., and Stuehr, D. J. (2004) The FAD-shielding residue Phe ${ }^{1395}$ regulates neuronal nitric-oxide synthase catalysis by controlling NADP affinity and a conformational equilibrium within the flavoprotein domain, J. Biol. Chem. 279, 35412-35425.

38. Adak, S., Ghosh, S., Abu-Soud, H. M., and Stuehr, D. J. (1999) Role of reductase domain cluster 1 acidic residues in neuronal nitric-oxide synthase. Characterization of the FMN-FREE enzyme, J. Biol. Chem. 274, 22313-22320.

39. Yuri, S., Regulski, M., Kuzin, B., Tully, T., and Enikolopov, G. (2001) The Drosophila nitric-oxide synthase gene (dNOS) encodes a family of proteins that can modulate NOS activity by acting as dominant negative regulators, J. Biol. Chem. 276, 42241-42251.

40. Yuri, S., Kuzin, B., Regulski, M., Tully, T., and Enikolopov, G. (2004) Regulation of multimers via truncated isoforms: a novel mechanism to control nitric-oxide signaling, Genes Dev. 18, $1812-1823$.

41. Gachhui, R., Presta, A., Bentley, D. F., Abu-Soud, H. M., McArthur, R., Brudvig, G., Ghosh, D. K., Stuehr, D. J. (1996) Characterization of the reductase domain of rat neuronal nitric oxide synthase generated in the methylotrophic yeast Pichia pastoris. Calmodulin response is complete within the reductase domain itself, J. Biol. Chem. 271, 20594-20602.

42. Guan, Z. W., Kamatani, D., Kimura, S., and Iyanagi, T. (2003) Mechanistic studies on the intramolecular one-electron transfer between the two flavins in the human neuronal nitric-oxide synthase and inducible nitric-oxide synthase flavin domains, $\underline{J}$. Biol. Chem. 278, 30859-30868.

43. Chen, P. F., and Wu, K. K. (2003) Structural elements contribute to the calcium/calmodulin dependence on enzyme activation in human endothelial nitric-oxide synthase, J. Biol. Chem. 278, $52392-52400$

44. Daff, D., Sagami, I., and Shimizu, T. (1999) The 42-amino acid insert in the FMN domain of neuronal nitric-oxide synthase exerts control over $\mathrm{Ca}^{2+} /$ calmodulin-dependent electron transfer, J. Biol. Chem., 274, 30589-30595.

45. Tiso, M., Konas, D. W., Panda, K., Garcin, E. D., Sharma, M., Getzoff, E. D., and Stuehr, D. J. (2005) C-terminal tail residue Arg1400 enables NADPH to regulate electron transfer in neuronal nitric-oxide synthase, J. Biol. Chem. 280, 39208-39219.

46. Presta, A., Liu, J., Sessa, W. C., and Stuehr, D. J. (1997) Substrate binding and calmodulin binding to endothelial nitric oxide synthase coregulate its enzymatic activity, Nitric Oxide 1, 74-87.

47. Davies, S. A., Stewart, E. J., Huesmann, G. R., Skaer, N. J., Maddrell, S. H., Tublitz, N. J., and Dow, J. A. (1997) Neuropeptide stimulation of the nitric oxide signaling pathway in Drosophila melanogaster Malpighian tubules, Am. J. Phvsiol. 273, R823R827.

48. Konas, D. W., Zhu, K., Sharma, M., Aulak, K. S., Brudvig, G. W., and Stuehr, D. J. (2004) The FAD-shielding residue Phe ${ }^{1395}$ regulates neuronal nitric-oxide synthase catalysis by controlling $\mathrm{NADP}^{+}$affinity and a conformational equilibrium within the flavoprotein domain, J. Biol. Chem. 279, 35412-35425.

49. Matsuda, H., and Iyanagi, T. (1999) Calmodulin activates intramolecular electron transfer between the two flavins of neuronal nitric oxide synthase flavin domain, Biochim. Biophvs. Acta 1473 345-355.

50. Craig, D. H., Chapman, S. K., and Daff, S. (2002) Calmodulin activates electron transfer through neuronal nitric-oxide synthase reductase domain by releasing an NADPH-dependent conformational lock, J. Biol. Chem. 277, 33987-33994.

51. Guan, Z. W., and Iyanagi, T. (2003) Electron transfer is activated by calmodulin in the flavin domain of human neuronal nitric oxide synthase, Arch. Biochem. Biophvs. 412, 65-76.

52. Panda, K., Adak, S., Konas, D., Sharma, M., and Stuehr, D. J. (2004) A conserved aspartate (Asp-1393) regulates NADPH reduction of neuronal nitric-oxide synthase: implications for catalysis, J. Biol. Chem. 279, 18323-18333.

53. Adak, S., Sharma, M., Meade, A. L., and Stuehr, D. J. (2002) A conserved flavin-shielding residue regulates $\mathrm{NO}$ synthase electron transfer and nicotinamide coenzyme specificity, Proc. Natl. Acad. Sci. U.S.A. 99, 13516-13521.

54. Nishida, C. R., and Ortiz de Montellano, P. R. (1999) Autoinhibition of endothelial nitric-oxide synthase. Identification of an electron transfer control element, J. Biol. Chem. 274, 1469214698.

55. Nathan, C. (1997) Inducible nitric oxide synthase: what difference does it make? J. Clin. Invest. 100, 2417-2423.

56. Sessa, W. C. (2005) Regulation of endothelial derived nitric oxide in health and disease, Mem. Inst. Oswaldo Cruz 100, 15-18.

57. McCabe, T. J., Fulton, D., Roman, L. J., and Sessa, W. C. (2000) Enhanced electron flux and reduced calmodulin dissociation may explain calmodulin dependent eNOS activation by phosphorylation, J. Biol. Chem. 275, 6123-6128.

58. Fulton, D., Gratton, J. P., McCabe, T. J., Fontana, J., Fujio, Y., Walsh, K., Franke, T. F., Papapetropoulos, A., and Sessa, W. C. (1999) Regulation of endothelium-derived nitric oxide production by the protein kinase Akt, Nature 399, 597-601.

59. Ghosh, S., Gachhui, R., Crooks, C., Wu, C., Lisanti, M. P., and Stuehr, D. J. (1998) Interaction between caveolin-1 and the reductase domain of endothelial nitric-oxide synthase. Consequences for catalysis, J. Biol. Chem. 273, 22267-22271.

BI700805X 